\title{
The loneliness of the original investigator
}

Ernest Borek of the University of Colorado Medical Center comments on the fate of original research under present funding arrangements

THE curse on science is that its masters demand results they can readily comprehend. Kings and princes once gave what we would call today research grants to their alchemists, expecting gold for their largesse. The alchemist Hennig Brandt serendipitously discovered that if he performed some hocus-pocus on dried urine, he obtained a magic stuff. It glowed in the dark! His patron, a German prince, was not impressed, so Brandt's grants continued to be miserly.

Of course, Brandt discovered phosphorous, and our knowledge of the universal need for this element in the form of phosphates by plants and the consequent incorporation of it into fertilizers has improved the yield of crops, producing wealth over the scores of years, which in value probably exceeds all the gold of the world.

Our situation today is not much different. We are the remittance men of Presidents and Royal Commissions. Science is in the political arena; we are at the mercy of the ringmasters. Charles G. Wilson, a Secretary of Defense whose department controlled enormous funds for research, pithily (if ungrammatically) aphorised the opinion of many upper level administrators on research: "Basic research is when you don't know what you're doing".

Five years ago the President of the United States decided, it being a preelection year, to sign the "Conquest of Cancer Act of 1971", and did so with a flourish. $\mathrm{He}$ invited a horde of television men, some legislators, and a sprinkling of scientists to witness the great moment. I am ashamed to admit that curiosity impelled me to accept the invitation. In those pre-Watergate days, I was almost touched when the president told us about his dear aunt who died of cancer. In less than a year he impounded a hundred million dollars from cancer research provided by the bill he signed with so much emotion.

The British scientist is also not free from the paralysing shackles of authority. A few months ago, a young Englishman spent a year in my laboratory learning the skills to study the modifications of $t R N A$. He went home filled with plans and enthusiasm. He actually made an observation which could have been developed into something very interesting. But soon I received a sad letter from him. The director of his research institute ordered him to drop studying modification of tRNA because the molecular biologist on some high MRC committee put a very low priority on such research. Chalones were in vogue.

Now this is hearsay and may be just sour grapes, but I could count on the fingers of one hand the British colleagues contributing visibly to this field. For the benefit of those who are not molecular biologists, I should point out that the primary structure of tRNA is made by one enzyme, but more than fifty modifications of it are achieved by perhaps 150 different enzymes. We know the functions of some of these modifications, but for most of them, the gold is not yet visible. tRNA is the most versatile of the biomacromolecules. In addition to its pivotal participation in protein synthesis, it can regulate transcription of DNA, translation of messenger RNA and can even control enzyme activity. What new roles will be revealed by patient probings cannot be predicted.

The American scientist who strives for originality is bedevilled at two levels of the governance of science. The General Accounting Office (GAO), which is the administration's watchdog over the budget, has recently urged Congress to require annual reviews of all research grants awarded by the National Institutes of Health (NIH). One can just see the staff at GAO with their tidy accountant's minds fretting over the possibility that some scientist may goof off for three years. After all, the corporations from where they came give quarterly reports of their earnings to the stockholders.

Unfortunately, at NIH the administrators urge the appointment of young investigators to peer review groups. James Watson is the most vocal champion of youth on advisory bodies because, he says, creativity is exclusively in the provenance of youth. This may be true in mathematics, but has no factual basis in the biological sciences. A young scientist becomes visible in biological research at an early age not by original major contributions but by frenetic publishing in a field opened by the origirality of others. Polish a little and publish a lot, that is the leitmotif of their research careers. "Peers" like that cannot possibly appreciate a new idea or a new approach. At the end of a two- or a three-year grant period, they measure accomplishment by counting pages rather than by the increment in our knowledge. The grant application of one of our most distinguished cell biologists went unfunded recently; the reason, he was told, was that his proposed experiments were too bold.

The members of advisory panels at the National Science Foundation (NSF) tend to be more mature and accomplished. But Congress insists that grants be awarded for only two years. How can one pose a challenging question and dare explore it when within a year it is time to write the grant renewal? At a recent conference on nucleic acid modification I noted that pre-eminence in the technology of tRNA modification has passed from America to Germany and Japan, and the reason must be that no one in his right mind would dare tackle such a problem on a twoyear NSF grant (Nature, September 9, 1976).

Some 25 years ago I became engrossed in Lwoff's discovery of lysogenic induction. In four years, we filled notebooks with observations I did not think were worth publishing. Had I depended on our current system of research support, I would have been washed out. Yet it is a matter of record that from those four years of observation came the discovery of "relaxed control" of RNA synthesis, indirect induction of latent virus, post-synthetic modification of nucleic acids, and the first qualitative difference in a biochemical component of a tumor versus a normal cell.

To beat the system some investigators resort to artful dodging. You describe in your grant application your second level ideas, or experiments you have already done and thus gain time and resources to bootleg explorations of your pet ideas. Five years ago I foolishly described, among other things, a programme of study in tissue slices or in vitro of the functional effects of hormone-induced modifications of tRNA. The critique relayed to me was that I had no experience in that field and the funding was proportionately reduced. Needless to say, I went on to do what I wanted (see J. Biol. Chem., 248. 762; 1973, and Nature, 262, 62; 1976).During these bootlegging operations, we observed serendipitously a novel attribute of the carcinogen ethionine (see Nature, 259, 588; 1976).

Many years ago while an undergraduate, I supported myself and my family as a waiter in a restaurant where one of my duties was selling bootleg whiskey. Now I bootleg my research. Plus ça change 